\title{
Uwarunkowania nierówności horyzontalnych w dostępie do szkolnictwa wyższego w Polsce
}

\begin{abstract}
STRESZCZENIE. W artykule przedstawiono wyniki badań nad statusem społeczno-ekonomicznym studentów kilku polskich uczelni różniących się pod względem prestiżu. Starano się w nim odpowiedzieć na pytanie: Co sprawia, że dana osoba wybiera studia na tej, a nie innej uczelni wyższej? Pytanie to ma szczególną wagę w kontekście polskiego systemu szkolnictwa wyższego, co do którego uzasadnione wydają się założenia o zróżnicowaniu jakościowym uczelni oraz wynikającym m.in. z umasowienia kształcenia na tym szczeblu zróżnicowaniu społecznym osób podejmujących studia na poszczególnych uczelniach. Dorobek badań nad nierównościami szans edukacyjnych wyraźnie sugeruje, że studenci uczelni o różnym poziomie prestiżu istotnie różnią się pod względem statusu społeczno-ekonomicznego. Potwierdzenie tej hipotezy w zgromadzonych danych pozwoliło na weryfikację kolejnej: można mówić o istnieniu horyzontalnych nierówności w dostępie do szkolnictwa wyższego w Polsce, czyli sytuacji, w której część osób podejmuje studia na uczelniach o niższym prestiżu z powodów innych niż przygotowanie szkolne (spełnianie kryteriów kwalifikacji). Interesujące przy tym jest nie tyle samo odnotowanie tego zjawiska, ile rozpoznanie jego zakresu oraz wywołujących go czynników, a także ich relatywnej siły. Mające temu służyć badanie ankietowe przeprowadzono w drugim kwartale 2015 r. na populacji polskich studentów I i II roku studiów I stopnia w dziedzinie nauk ekonomicznych na uczelniach publicznych i niepublicznych w Polsce.
\end{abstract}

SŁOWA KLUCZOWE: nierówności szans edukacyjnych, szkolnictwo wyższe, status społeczno-ekonomiczny

\section{Wprowadzenie}

W dyskursie naukowym edukacja wyższa coraz częściej uznawana jest za ważny element państwa opiekuńczego (Busemeyer i Nikolai 2010; Czarnecki 2013; Kwiek 2014). Poprzez regulacje prawne, szczególnie dotyczące zasad przyznawania dota- 
cji publicznych, polityka w obszarze szkolnictwa wyższego może wpływać na zróżnicowanie uczelni pod względem prestiżu. Ponieważ prestiż ukończonej uczelni wyższej jest sygnałem odbieranym przez pracodawców na rynku pracy (Chattopadhyay 2012; Rivera 2015), zróżnicowanie to może, ceteris paribus, ograniczać relatywne szanse rozwoju osobistego i karier zawodowych studentów, którzy z różnych powodów nie mogli podjąć studiów na „lepszych” uczelniach (Teichler 2007). Wyraźne zróżnicowanie podaży (uczelni, ale i kierunków kształcenia) pod względem prestiżu może więc prowadzić do zwiększenia nierówności horyzontalnych w dostępie do szkolnictwa wyższego, czyli sytuacji, w której część osób podejmuje studia na „gorszych" uczelniach z powodów innych niż przygotowanie szkolne (spełnianie kryteriów kwalifikacji)ㄹ, a w konsekwencji do ograniczenia pionowej mobilności społecznej (por. teoria dóbr pozycjonalnych w kontekście edukacji na poziomie wyższym: Stankiewicz 2014).

Funkcja szkolnictwa wyższego polegająca na dokonywaniu selekcji społecznych, jak również powiązane z nią problemy badawcze zyskują w ostatnich latach na znaczeniu z dwóch powodów. Po pierwsze, umasowienie studiów i zahamowanie wzrostu liczby miejsc pracy wymagających wysokich kwalifikacji doprowadziły w wielu krajach do powstania nadwyżki osób wykształconych na rynku pracy (Shavit, Arum i Gamoran 2007). Neoliberalna interpretacja tych zjawisk sprawiła, że równość szans na kształcenie na poziomie wyższym straciła na znaczeniu w hierarchii celów politycznych (Marginson 1997). Wraz z umasowieniem studiów zaczęło pogłębiać się zróżnicowanie uczelni w zakresie jakości kształcenia i wartości dyplomów (Marginson 2004; Triventi 2013). Jednocześnie zwiększa się wpływ prestiżu ukończonej uczelni na trajektorię karier zawodowych, warunki i jakość życia oraz dochody (Teichler 2007). A zatem w kontekście współczesnych problemów absolwentów na rynku pracy oraz spadającej i różnicującej się stopy zwrotu z inwestycji w uzyskanie dyplomu uczelni wyższej (Checchi 2006) nierówności horyzontalne w szkolnictwie wyższym mogą mieć wpływ na stratyfikację społeczną i międzygeneracyjną mobilność społeczną (Reimer i Pollak 2010).

Niniejszy artykuł koncentruje się na determinantach nierówności horyzontalnych po stronie popytu, czyli czynnikach statusu społeczno-ekonomicznego (SSE) wpływających na decyzje jednostek o podjęciu studiów na danej uczelni. Celem analizy jest poszerzenie wiedzy na temat czynników wpływających na rozkład efektywnego popytu na studia pomiędzy uczelniami o zróżnicowanym prestiżu. Popyt efektywny rozumiany jest jako zbiorowość osób studiujących (Szambelańczyk 1982). Jego rozkład jest konsekwencją indywidualnych decyzji dotyczących tego a) na jaką lub jakie uczelnie aplikować, a następnie, po procesie rekrutacyjnym, b) na której uczelni podjąć studia. Decyzje te podejmowane są w kontek-

${ }^{1}$ Jak ujął to Zbigniew Sawiński, w ujęciu horyzontalnym „przedmiot rywalizacji różnych grup społecznych stanowi jakość wykształcenia, nie zaś jego ilość, czyli jego poziom” (Sawiński 2013: 115). 
ście stałej podaży, czyli możliwych do wyboru uczelni o zróżnicowanym prestiżu. Można uznać, że na prestiż składają się: elitarność studiów na danej uczelni (zob. selekcyjność podczas procesu rekrutacji), jakość kształcenia i prowadzonych na niej badań, a także usytuowanie ośrodka akademickiego, mające wpływ na przyszłe zarobki absolwentów, a przez to na oczekiwaną stopę zwrotu z indywidualnej inwestycji w edukację na danej uczelni². Do czynników warunkujących decyzje zaliczone zostały: status społeczno-ekonomiczny (SSE), dyspozycje oraz praktyki jednostek świadczące o poziomie posiadanego przez nie kapitału kulturowego i społecznego, a także osiągnięcia edukacyjne.

\section{Przegląd dotychczasowych badań}

Podstawową obserwacją płynącą z badań nad nierównościami szans edukacyjnych (inequalities of educational opportunity - IEO) jest wyraźny w ostatnich dziesięcioleciach spadek nierówności wertykalnych w dostępie do edukacji wyższej w krajach rozwiniętych - wzrasta odsetek osób o nieuprzywilejowanym położeniu społecznym, które podejmują studia (Jackson 2013). Ostatnie badania porównawcze prowadzone w Europie Zachodniej dowodzą jednak, że równolegle do tego zjawiska wśród studiujących wzrasta odsetek dzieci z rodzin lepiej sytuowanych, w związku z czym relatywny udział osób o niższym SSE w popycie efektywnym nie zmienia się istotnie na ich korzyść (Shavit i in. 2007). Jak dotąd niewiele przeprowadzono szeroko zakrojonych badań nad nierównościami horyzontalnymi, mimo że ich narastanie jest w literaturze wyraźnie sugerowane (teoria skutecznego utrzymywania nierówności: Lucas 2001). Najczęściej badania te dotyczą dostępu do elitarnych szkół wyższych (trafiają na podatny grunt szczególnie w Stanach Zjednoczonych; Martin i Spenner 2009; Hoxby i Avery 2013) oraz do prestiżowych kierunków studiów (temat eksplorowany także w Europie; Reimer i Pollak 2010; Hällsten 2010; Kraaykamp, Tolsma i Wolbers 2013). Wskazują one jednoznacznie na istnienie znacznych nierówności horyzontalnych - SSE wciąż wpływa więc istotnie na ścieżki karier edukacyjnych. Wśród teorii opisujących i wyjaśniających te zjawiska do najbardziej wpływowych należy zaliczyć teorię racjonalnego działania (RAT) (Breen i Goldthorpe 1997) oraz teorię reprodukcji społecznej (Bourdieu i Passeron 2006).

${ }^{2}$ Prestiż jest $\mathrm{z}$ definicji czynnikiem relatywnym, będącym wypadkową sposobów postrzegania uczelni przez różnych interesariuszy. Z tego względu obiektywne określenie hierarchii prestiżu uczelni nastręcza istotnych trudności, co nie podważa jednak trafności zdroworozsądkowej obserwacji, że taka hierarchia istnieje. $\mathrm{W}$ badaniu uczelnie, w których przeprowadzano ankiety, zostały przez autora przyporządkowane do czterech kategorii w sposób arbitralny, na podstawie wymienionych kryteriów oraz dostępnych rankingów. W samej analizie zaś kategorie te zostały ujęte jako wartości nominalnej zmiennej zależnej. 
Badania nurtu RAT zazwyczaj konceptualizują SSE pod pojęciem klasy społecznej. Dowodzą one, że dzieci rodziców dobrze wykształconych i/lub wykonujących bardziej prestiżowe zawody nie tylko osiągają lepsze wyniki w szkole (tzw. pierwotny efekt stratyfikacyjny), lecz także podejmują bardziej ambitne decyzje o wyborze ścieżek edukacyjnych i zawodowych (tzw. wtórny efekt stratyfikacyjny - primary oraz secondary effects; Borowicz 1988: 73; Boudon 1974; Jackson 2013). Znaczy to np., że wśród młodzieży spełniającej kryteria przyjęć na dane studia decyzje o ich rozpoczęciu częściej podejmują osoby o uprzywilejowanym pochodzeniu społecznym. Nierówności szans edukacyjnych byłyby więc istotnie zmniejszone, jeśli efekty wtórne zostałyby zredukowane (Jackson 2013: 12). W przeciwieństwie do efektów pierwotnych efekty wtórne wydają się możliwe do złagodzenia dzięki polityce społecznej polegającej na manipulacji kosztami studiowania za pomocą systemu pomocy materialnej dla studentów (Paulsen 1990). Badania omawianego nurtu dostarczają empirycznych dowodów kwestionujących dominujące w ekonomii edukacji przekonanie, że nierówności w dostępie do szkolnictwa wyższego są skumulowanym efektem zaniedbań na wczesnym etapie kształcenia (Checchi 2006), choć faktycznie wpływ pochodzenia społecznego na obraną ścieżkę edukacyjną zmniejsza się wraz z przechodzeniem na kolejne szczeble edukacji. Mimo to pochodzenie społeczne istotnie różnicuje nawet decyzje edukacyjne podejmowane po ukończeniu szkoły średniej (Lucas 2001; Perna 2010).

Pierre Bourdieu wyróżnia w swojej teorii trzy rodzaje kapitałów: społeczny, kulturowy i ekonomiczny, w które jednostki są wyposażone (endowed) lub do których mają dostęp w stopniu różnym, zmiennym i zależnym w dużej mierze od społecznej klasy pochodzenia. Ilość i kompozycja kapitałów wpływają na aspiracje i wybory edukacyjne (Bourdieu 1986). O tym, jak kapitały „pracują” w polu edukacji, będzie mowa dalej, gdy będą operacjonalizowane na potrzeby badania. System edukacyjny (a zwłaszcza nadawane przez niego dyplomy) postrzegany jest natomiast jako narzędzie reprodukcji społecznej (por. Collins 1979). Hierarchizacja szkół wyższych umożliwia więc klasom dominującym utrzymanie uprzywilejowanej pozycji w strukturze społecznej (Bourdieu i Passeron 2006).

W Polsce badania nad popytem na edukację wyższą były prowadzone głównie w latach 70. i 80. XX wieku (np. Borowicz 1976; Szambelańczyk 1982; Sawiński i Stasińska 1986). Wobec znaczącego wzrostu poziomu skolaryzacji w ostatnich dwóch dekadach zainteresowanie tym tematem wyraźnie osłabło, choć w niektórych ośrodkach akademickich wciąż kontynuowane są wieloletnie tradycje badań nad nierównościami edukacyjnymi (Mikiewicz 2014; Wasielewski 2013). Większość badań dotyczyła jednak zmian poziomu nierówności wertykalnych w dostępie do edukacji (Domański 2004). Problematyka nierówności horyzontalnych jest na ogół pomijana w polskim dyskursie naukowym i publicznym, w którym dominuje raczej przekonanie o zbyt łatwym dostępie do edukacji wyższej. W konsekwencji brakuje danych, które pozwoliłyby kompleksowo zanalizować uwarunkowania 
tych problemów. Najnowsze prace wskazują jednak na nierówności wyłaniające się podczas procesów selekcji studentów na studia stacjonarne lub niestacjonarne, płatne lub bezpłatne (Herbst i Rok 2014) oraz na kierunki studiów (Zawistowska 2012). Praca Alicji Zawistowskiej obejmuje także przegląd teorii socjologicznych wyjaśniających utrzymywanie się nierówności edukacyjnych.

Kontekst instytucjonalny także sugeruje istnienie znacznych nierówności horyzontalnych. Na tle innych wysoko rozwiniętych krajów europejskich Polska charakteryzuje się najniższym poziomem publicznych świadczeń pieniężnych przeznaczanych dla studentów i ich rodzin, wysokim stopniem umasowienia studiów przy zasadniczo ujednoliconych kryteriach wejścia (wyniki matury), znacznym zróżnicowaniem uczelni i studiów pod względem prestiżu oraz wysokim odsetkiem studentów płacących za studia (niestacjonarne i na uczelniach niepublicznych), które z reguły cieszą się mniejszą renomą (Czarnecki 2014). A zatem uzasadnione wydaje się postawienie następujących pytań badawczych:

1. W jaki sposób międzyosobowe różnice pod względem SSE wpływają na rozkład efektywnego popytu na studia?

2. W jakim stopniu wpływ wywierany przez SSE niezależny jest od osiągnięć edukacyjnych?

Do odpowiedzi na te pytania posłuży model teoretyczny, którego wyjściowa postać, oparta na analizie literatury przedmiotu, została przedstawiona poniżej.

\section{Model - konceptualizacja i operacjonalizacja}

Wyjściowy model teoretyczny (rys. 1) obejmuje sześć zmiennych obserwowalnych i dwie zmienne ukryte (kapitał społeczny i kapitał kulturowy). Zostały one zestawione w sposób dążący do odzwierciedlenia schematu wyjaśniania zjawisk społecznych, w którym czynniki strukturalne (tu: wykształcenie i zawód rodziców, kapitał ekonomiczny pod postacią sytuacji materialnej rodziny) warunkują wiele jednostkowych dyspozycji i praktyk społecznych (kapitał społeczny i kulturowy, osiągnięcia edukacyjne, kapitał ekonomiczny pod postacią dochodu rozporządzalnego) wpływających następnie na prawdopodobieństwo zaistnienia badanego zjawiska, czyli podjęcia studiów na danej uczelni (Nash i Lauder 2010). Strzałki na rysunku wyrażają hipotetyzowaną zależność, której istotność, kierunek i siła będą przedmiotem analizy.

Zmienna wyjaśniana. Podażowy wymiar uwarunkowań nierówności horyzontalnych odzwierciedlony jest w sposobie kategoryzacji zmiennej wyjaśnianej (studia na danej uczelni). Zmienna ta ma charakter nominalny - uczelnie zostały przyporządkowane do czterech kategorii mających odzwierciedlać jakościowe spektrum możliwości studiowania kierunków z dziedziny nauk ekonomicznych w Polsce (ekonomia, finanse, nauki o zarządzaniu, towaroznawstwo): prywatne 
masowe, publiczne masowe, publiczne prestiżowe, elitarne uczelnie stołeczne. Masowe uczelnie to uczelnie usytuowane w mniejszych ośrodkach akademickich, przyjmujące zdecydowaną większość kandydatów. Uczelnie prestiżowe, mimo presji związanej z niżem demograficznym, wciąż dokonują pewnej selekcji kandydatów na studia. Elitarne uczelnie stołeczne zajmują pierwsze miejsca w rankingach, a także przyciągają perspektywami zawodowymi związanymi z życiem w Warszawie.

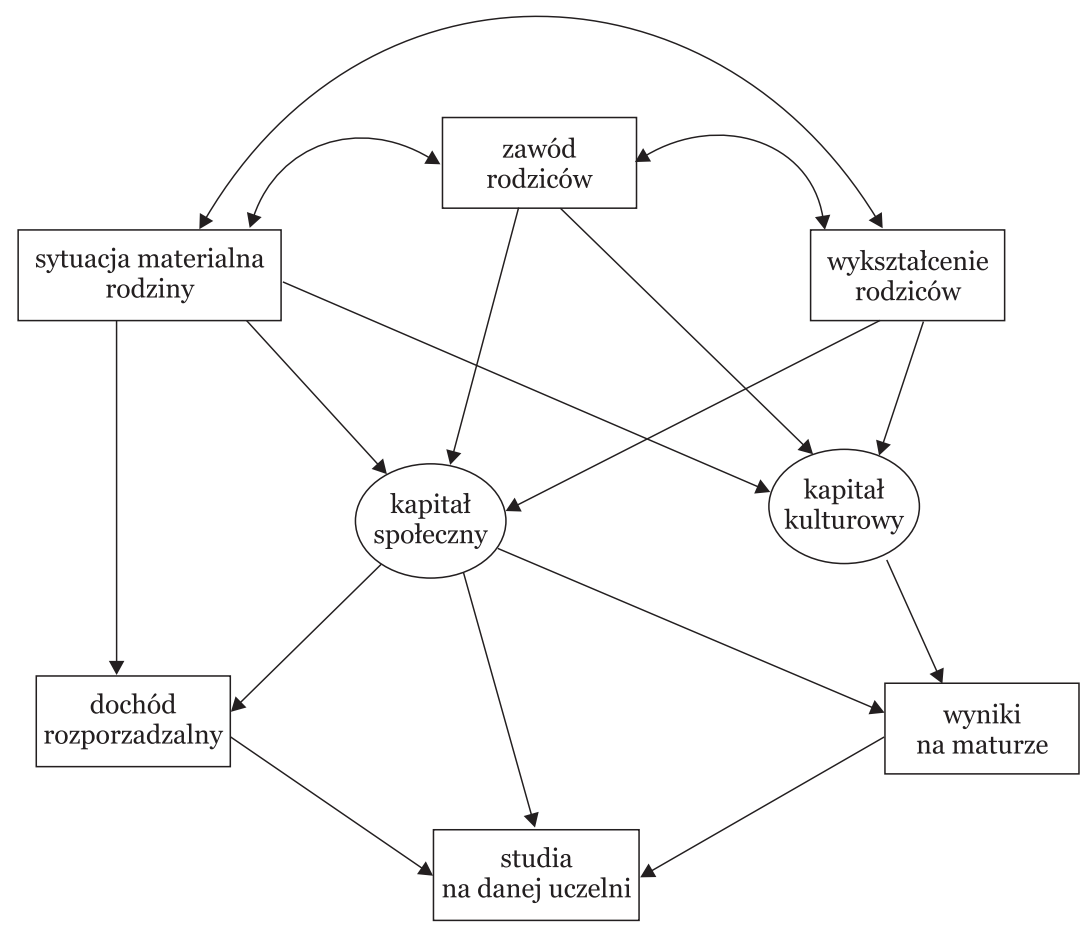

Rysunek 1. Wyjściowy model uwarunkowań wyboru uczelni

Źródło: opracowanie własne.

Zmienne wyjaśniające (SSE). Status społeczno-ekonomiczny, jako strukturalne uwarunkowanie decyzji edukacyjnych, skonceptualizowany został pod postacią trzech zmiennych: wykształcenie rodziców, zawód rodziców i sytuacja materialna rodziny, będących klasycznymi zmiennymi stanowiącymi o przynależności klasowej i powszechnie identyfikowanymi w badaniach nad nierównościami szans edukacyjnych (IEO) jako czynniki determinujące przebieg ścieżki edukacyjnej dzieci (Breen i Jonsson 2005). Zmiennej „wykształcenie rodziców” przypisano trzy kategorie: wyższe, posiadanie matury oraz nieposiadanie matury. $\mathrm{W}$ analizie uwzględniono najwyższą wartość poziomu wykształcenia rodziców, co oznacza, że 
wartość zmiennej dla studentów posiadających tylko jednego rodzica z wyższym wykształceniem jest taka sama jak dla studentów, których oboje rodzice ukończyli studia. Analogiczne rozwiązanie przyjęto w odniesieniu do zmiennej „zawód rodziców", obejmującej cztery kategorie stworzone na podstawie schematu podziału klasowego autorstwa Johna Goldthorpe'a i Roberta Eriksona (1992) i odnoszące się do prestiżu zawodu oraz stopnia podporządkowania stanowiska pracy: klasa robotnicza, klasa średnia niższa, klasa średnia wyższa, klasa wyższa. Zmienna „sytuacja materialna rodziny” to ocena relatywnej sytuacji materialnej rodziny, dokonana przez respondentów na 7-stopniowej skali, której wartość neutralną określono jako „podobna do przeciętnej polskiej rodziny (80o zł miesięcznie na członka rodziny)", przy czym respondentów poproszono o uwzględnienie nie tylko dochodu, lecz także posiadanego przez rodzinę (a więc nie tylko rodziców) majątku. Uznano, że może to dać pełniejszy obraz zróżnicowania społecznego w tym zakresie niż typowe pytanie o dochody z pracy, ograniczając przy tym braki danych. Kapitał ekonomiczny rodziny może istotnie sprzyjać osiągnięciom edukacyjnym dzieci (np. wysłanie dziecka do elitarnego, prywatnego liceum, opłacanie kursów językowych), a także umożliwiać im podejmowanie bardziej ryzykownych i kosztownych decyzji edukacyjnych - w przypadku niepowodzenia koszty utraconych korzyści (np. zarobki utracone z powodu odroczonego wejścia na rynek pracy) są mniej dotkliwe dla osób posiadających zabezpieczenie materialne (Knowles 2000; Checchi 2006). W modelu wyjściowym założono, że zmienne SSE są ze sobą skorelowane.

Zmienne wyjaśniające (dyspozycje i praktyki społeczne). Kapitał ekonomiczny to nie tylko środki finansowe i majątek posiadany przez rodzinę, lecz także „dochód rozporządzalny” studenta w czasie studiów, który zależy oczywiście od sytuacji materialnej rodziny, lecz niekoniecznie musi być jej prostym odzwierciedleniem ze względu na zachodzący w czasie studiów proces uniezależniania się młodych dorosłych od rodziców. Ponadto założono, że osoba, będąc świadomą dostępności potencjalnych źródeł utrzymania na studiach (rodzina, praca, stypendia, oszczędności, dostęp do mieszkania), uzależnionej często od relacji społecznych, w jakie jest uwikłana (stąd też zakładany wpływ kapitału społecznego na dochód rozporządzalny), uwzględnia je w procesie decyzyjnym dotyczącym wyboru uczelni.

Uznano, że ujęcie „klasy społecznej” jako wykształcenia rodziców, pozycji w strukturze zawodowej oraz sytuacji materialnej rodziców nie oddaje wystarczająco heterogeniczności absolwentów szkół średnich. Ogranicza także możliwości eksplanacyjne, gdyż „klasa” jest czynnikiem warunkującym konkretne dyspozycje i praktyki jednostek, które stanowią o różnicach istotnych w kontekście edukacyjnym oraz wpływają na aspiracje i wybory edukacyjne (Bourdieu 1998: 10-13; Jæger i Holm 2007). Dyspozycje i praktyki zostały więc skonceptualizowane jako „wyposażenie” jednostek w trzy rodzaje kapitałów: ekonomiczny (dochód rozporządzalny), społeczny i kulturowy. Ich odrębność znajduje teoretyczne i empirycz- 
ne uzasadnienie (Bourdieu 1986; Martin i Spenner 2009). Jednostki wyposażone są w różne ilości i kombinacje tych kapitałów. Poprzez „wyposażenie” w kapitał rozumiana jest zdolność i możliwość jego aktywacji wówczas, gdy jest to potrzebne - w tym przypadku w kontekście procesów przejścia między dwoma poziomami edukacji, które wymagają od jednostki podejmowania decyzji i działań (np. odpowiednie przygotowanie do egzaminów, rozpoznanie możliwości studiowania) we własnym interesie.

Kapitał społeczny (KS) to sieć mniej lub bardziej zinstytucjonalizowanych powiązań oraz relacji międzyludzkich, umożliwiająca korzystanie z zasobów innych osób. KS jest tu rozumiany jako zasób relacyjny, a więc w sposób bliski ujęciu Pierre'a Bourdieu (1986) i Nana Lina (1999). W związku z tym akcent położony jest na „zaktywizowane” zasoby KS, czyli stopień, w jakim na aspiracje i wybory studentów oddziaływała presja rówieśnicza i rodzinna, a także stopien, w jakim korzystali oni z porad otoczenia (rodzina, znajomi, nauczyciele) podczas podejmowania decyzji o podjęciu studiów. Znajomość ludzi, którzy posiadają wiedzę na temat systemu szkolnictwa wyższego i perspektyw związanych z obraniem danej ścieżki kształcenia, a także poziom aspiracji edukacyjnych w środowisku rówieśniczym są czynnikami, których wpływ na osiągnięcia i decyzje edukacyjne jest szeroko udokumentowany (Mikiewicz 2014). W modelu wyjściowym KS został ujęty jako zmienna ukryta, czyli swoisty wskaźnik skonstruowany na podstawie zmiennych obserwowalnych wymienionych w tabeli 10.

Kapitał kulturowy (KK) to znajomość kodu kulturowego dominującego $\mathrm{w}$ danym polu, $\mathrm{w}$ tym przypadku posiadanie dyspozycji do postaw i zachowań aprobowanych w określonych grupach społecznych (np. oczekiwania nauczycieli akademickich na prestiżowej uczelni wobec języka, jakim posługują się studenci, styl życia studentów danej uczelni) (Bourdieu 1986). Bourdieu identyfikuje trzy rodzaje kapitału kulturowego: ucieleśniony, czyli dyspozycje do określonych postaw i zachowań (np. związanych z praktykami czytelniczymi, uczeniem się, zdobywaniem i przetwarzaniem informacji), uprzedmiotowiony, czyli dostęp do zasobów kulturowych, takich jak książki, dzieła sztuki, oraz zinstytucjonalizowany, czyli korzystanie z instytucji przekazujących uprawomocnioną wiedzę (np. korepetycje). KK umożliwia właściwe poruszanie się w gąszczu informacji o edukacji wyższej, wpływa na aspiracje dotyczące wykształcenia i środowiska społecznego, jakim jednostka chce się otaczać, oraz pomaga w opanowaniu „zasad gry”, czyli właściwym przygotowaniu się do egzaminów i podjęcia studiów (DiMaggio i Mohr 1985; De Graaf i in. 2000; Hart 2012). W modelu KK także został ujęty jako zmienna ukryta, mierzona liczbą książek, do których osoba miała dostęp w domu rodzinnym w okresie szkoły średniej, jej ówczesnymi zwyczajami i preferencjami czytelniczymi oraz częstotliwością uczestniczenia w zajęciach pozalekcyjnych i korepetycjach. Zmienne te powinny być też skorelowane z wynikami osiąganymi na maturze. 
Dotychczasowe osiągnięcia edukacyjne sprzyjają dalszym osiągnięciom edukacyjnym, szczególnie gdy są jedynym kryterium selekcji do dalszych etapów kształcenia, jak to ma miejsce w przypadku polskiej matury. Osoby o niższym poziomie osiągnięć mogą antycypować porażkę w procesie rekrutacyjnym lub trudności z zaliczaniem egzaminów na danej uczelni i w konsekwencji podejmować mniej ambitne decyzje edukacyjne (Pascarella i Terenzini 2005). W badaniu wskaźnikiem osiągnięć edukacyjnych jest suma wyników z matury z matematyki i języka obcego na poziomie podstawowym, gdyż są to egzaminy obowiązkowe dla wszystkich badanych studentów, a także istotne z punktu widzenia szans na przyjęcie na kierunki z dziedziny nauk ekonomicznych. W modelu „wyniki na maturze” zostały ujęte jako zależne od SSE oraz wyposażenia w kapitał kulturowy i społeczny, w sposób odzwierciedlający ścieżkę tzw. pierwotnego efektu stratyfikacyjnego identyfikowanego w nurcie badań IEO, sięgających w tym zakresie do teorii Raymonda Boudona (Jackson 2013). Jednocześnie, wybór uczelni uzależniony jest bezpośrednio od SSE i wyposażenia w kapitały (tzw. wtórny efekt stratyfikacyjny).

\section{Metodyka badań}

Badanie zostało przeprowadzone wiosną 2015 r. na sześciu uczelniach prowadzących studia I stopnia w dziedzinie nauk ekonomicznych ${ }^{3}$. Objęcie analizą studentów tylko jednej dziedziny ogranicza możliwości generalizacji wniosków. Pozwala jednak na przeprowadzenie testu złożonego modelu, w którym narzędzie pomiaru i dobór zmiennych dostosowane są do kontekstu instytucjonalnego, co jest szczególnie istotne przy badaniu systemów szkolnictwa wyższego cechujących się dużym zróżnicowaniem (Perna 2010). Kryterium doboru i przyporządkowania uczelni do jednej z czterech wymienionych wcześniej kategorii był prestiż uczelni. Pod uwagę brane były tylko te uczelnie, które prowadzą studia w dziedzinie nauk ekonomicznych i znajdują się w jednym środowisku konkurencyjnym (można założyć, że konkurują w dużej mierze o tę samą pulę absolwentów szkół średnich). Zostało one określone na podstawie badania pilotażowego (Czarnecki i Zając 2015), celem zredukowania wpływu dystansu i różnic geograficznych na badane zjawiska.

Pomiaru dokonano przy użyciu kwestionariusza dystrybuowanego w wersji elektronicznej za pośrednictwem administracji badanych uczelni oraz w wersji pa-

${ }^{3}$ Badaniem nie objęto więc zbiorowości osób niestudiujących. Znajduje to następujące uzasadnienie: a) przedmiotem badania są tylko różnice między osobami studiującymi na uczelniach różniących się pod względem prestiżu; b) konieczne byłyby wówczas badania panelowe, trudne do zrealizowania w obliczu ograniczonych środków przeznaczonych na badanie oraz ograniczeń czasowych; c) odsetek młodzieży polskiej, która nie decyduje się w pewnym momencie na podjęcie studiów, jest wciąż niewielki - współczynnik „wejścia” (entry rate, miara skolaryzacji stosowana przez OECD) do szkolnictwa wyższego wyniósł w 2012 r. 79\% (OECD 2014). 
Tabela 1. Rozkład obserwacji pomiędzy kategoriami uczelni

\begin{tabular}{|l|c|c|c|c|}
\hline \multicolumn{1}{|c|}{ Kategoria uczelni } & \multicolumn{1}{c|}{$n$} & \multicolumn{1}{c|}{$\%$} & Liczebność populacji (ca) & Wielkość próby (\%) \\
\hline Prywatne masowe & 328 & 32,0 & 8000 & 4,1 \\
Publiczne masowe & 205 & 20,0 & 1460 & 14 \\
Publiczne prestiżowe & 354 & 34,5 & 1750 & 20,2 \\
Elitarne stołeczne & 139 & 13,5 & 2500 & 5,6 \\
\hline Ogółem & 1026 & 100,0 & 13210 & 7,77 \\
\hline
\end{tabular}

Źródło: opracowanie własne.

pierowej, gdy współpraca z administracją okazywała się niemożliwa lub nie przynosiła pożądanych efektów. Przeprowadzenie ankiety w drugim semestrze pozwoliło na pominięcie osób, które zrezygnowały ze studiów na samym ich początku. Badanie tylko dwóch roczników (I i II rok studiów licencjackich) umożliwiło dalszą homogenizację badanej populacji, uzasadnioną koniecznością kontroli różnic pomiędzy studentami różnych kierunków (o istotności tych różnic: Zawistowska 2012). Próba liczyła łącznie 1601 obserwacji. Po usunięciu obserwacji zawierających zbyt wiele braków danych liczebność próby zmniejszyła się do 1026. Rozkład próby pomiędzy kategoriami uczelni przedstawia tabela 1 .

Po zebraniu danych i przygotowaniu ich do analizy przeprowadzono wstępną analizę opisową dla zmiennych z modelu. Następnie, za pomocą modelowania równań strukturalnych (SEM), przeprowadzono test omówionego wyżej wyjściowego modelu teoretycznego. SEM identyfikuje takie same zależności co modele regresji, lecz pozwala oszacować błąd pomiaru $(\varepsilon)$ dla każdej zmiennej obserwowalnej oraz efekt zakłóceń (disturbance effect) dla zmiennej zależnej. Procedura modelowania równań strukturalnych składa się z dwóch etapów:

- pomiaru (measurement stage) - konfirmacyjna analiza czynnikowa, czyli w tym przypadku weryfikacja, na ile uzasadniona jest konceptualna odmienność zmiennych ukrytych: KS i KK, oraz które zmienne obserwowalne (wskaźniki) najlepiej służą ich pomiarowi.

- strukturalnego (model ścieżkowy) - wpływ wyróżnionych zmiennych na podjęcie studiów na uczelni danej kategorii zostanie zbadany za pomocą wielomianowej regresji logistycznej w ramach zgeneralizowanego SEM (gSEM), z wykorzystaniem pakietu statystycznego Stata13. Zastosowanie gSEM jako metody dopasowywania modelu do danych nakłada na badacza wiele ograniczeń, jest jednak konieczne w związku z nominalnym charakterem zmiennej zależnej.

$\mathrm{W}$ przypadku braku akceptowalnego dopasowania modelu wyjściowego do danych na każdym etapie SEM możliwa jest modyfikacja modelu poprzez zastosowanie innego układu relacji między zmiennymi lub ich usunięcie. Postępowanie badawcze polega więc na przechodzeniu od teorii do obserwacji i z powrotem, aż do osiągnięcia pożądanej dobroci dopasowania modelu do danych (Kline 2011). 


\section{Wyniki - statystyki opisowe}

Ze względu na brak dostępu do odpowiednich danych na temat badanej populacji nie było możliwe przeprowadzenie doboru losowego. Tym samym nie można mówić o reprezentatywności danych, jednak w pewnym stopniu rekompensują to liczebności obserwacji zebranych na poszczególnych uczelniach, a także dość dobre odzwierciedlenie w próbie istotnych cech populacji, takich jak proporcja kobiet i mężczyzn (odpowiednio 68\% i 30,4\%), studentów stacjonarnych i niestacjonarnych (70,7\% i 29,3\%) oraz osób pobierających stypendia socjalne $(15,2 \%)$ i rektorskie (12,1\% studentów II roku). Ponadto dane zawarte w tabeli 2 potwierdzają, że na studia na „lepszych” uczelniach trafiają przede wszystkim absolwenci liceów ogólnokształcących (ponad 90\%). Na uczelniach prywatnych i masowych absolwenci techników stanowią natomiast blisko 40\%. Wszystkie dokonane poniżej zestawienia zostały powtórzone na przeważonych obserwacjach, lecz uzyskane $\mathrm{w}$ ten sposób wyniki nie różniły się znacząco od tych uzyskanych na próbie. Ze względu na to, że w SEM przy bardzo dużej liczbie obserwacji parametry bywają przeszacowywane, dalsza prezentacja będzie odnosiła się do zebranej próby, a nie populacji, z której została pozyskana.

Tabela 2. Typ ukończonej szkoły średniej (w \%)

\begin{tabular}{|l|c|c|c|c|c|}
\hline \multicolumn{1}{|c|}{ Typ szkoły } & $\begin{array}{c}\text { Prywatne } \\
\text { masowe }\end{array}$ & $\begin{array}{c}\text { Publiczne } \\
\text { masowe }\end{array}$ & $\begin{array}{c}\text { Publiczne } \\
\text { prestiżowe }\end{array}$ & $\begin{array}{c}\text { Elitarne } \\
\text { stołeczne }\end{array}$ & Ogółem \\
\hline LO & 47,9 & 57,6 & 92,1 & 94,2 & 71,3 \\
Liceum profilowane & 11,0 & 5,9 & 1,1 & 3,6 & 5,6 \\
Technikum & 39,9 & 36,1 & 6,8 & 2,2 & 22,6 \\
Zasadnicza szkoła zawodowa/ & 1,2 & 0,5 & 0,0 & 0,0 & 0,5 \\
technikum uzupełniające/ & & & & & \\
liceum uzupełniające & & & & & \\
\hline
\end{tabular}

Źródło: opracowanie własne.

Status społeczno-ekonomiczny - wykształcenie i zawód rodziców. Tabela 3 ukazuje wyraźne zróżnicowanie studentów poszczególnych kategorii uczelni pod względem wykształcenia rodziców i wykonywanego przez nich zawodu. Czynnikiem najwyraźniej różnicującym zdaje się być posiadanie wyższego wykształcenia przez co najmniej jedno z rodziców, a najmniej - przynależność do klasy średniej niższej. Warto jednak zauważyć, że oprócz posiadania wyższego wykształcenia tylko ona różnicuje studentów uczelni masowych i prestiżowych. Dzieci rodziców z wyższym wykształceniem i z co najmniej klasy średniej wyższej stanowią 11\% studentów masowych uczelni prywatnych, 28,3\% - masowych uczelni 
Tabela 3. Wykształcenie i zawód rodziców

\begin{tabular}{|c|c|c|c|c|c|c|c|c|c|}
\hline \multirow{3}{*}{\multicolumn{2}{|c|}{$\begin{array}{c}\text { Status } \\
\text { społeczno-ekonomiczny }\end{array}$}} & \multicolumn{8}{|c|}{ Kategoria szkoły wyższej } \\
\hline & & \multicolumn{2}{|c|}{$\begin{array}{l}\text { prywatne } \\
\text { masowe }\end{array}$} & \multicolumn{2}{|c|}{$\begin{array}{l}\text { publiczne } \\
\text { masowe }\end{array}$} & \multicolumn{2}{|c|}{$\begin{array}{l}\text { publiczne } \\
\text { prestiżowe }\end{array}$} & \multicolumn{2}{|c|}{$\begin{array}{l}\text { elitarne } \\
\text { stołeczne }\end{array}$} \\
\hline & & $N$ & $\%$ & $N$ & $\%$ & $N$ & $\%$ & $N$ & $\%$ \\
\hline \multirow{3}{*}{$\begin{array}{l}\text { Wykształcenie } \\
\text { rodziców }\end{array}$} & brak matury & $146_{a}$ & 44,5 & $65 \mathrm{~b}$ & 31,7 & $8 \mathrm{O}_{\mathrm{b}}$ & 22,6 & $9 \mathrm{c}$ & 6,5 \\
\hline & matura & $126_{a}$ & 38,4 & $61_{\mathrm{a}, \mathrm{b}}$ & 29,8 & $91_{b}$ & 25,7 & $17 \mathrm{c}$ & 12,2 \\
\hline & wyższe & $56_{a}$ & 17,1 & $79 \mathrm{~b}$ & 38,5 & $183_{c}$ & 51,7 & $113 \mathrm{~d}$ & 81,3 \\
\hline \multirow[t]{4}{*}{$\begin{array}{l}\text { Zawód } \\
\text { rodziców }\end{array}$} & $\begin{array}{l}\text { klasa } \\
\text { robotnicza }\end{array}$ & $152_{a}$ & 46,3 & $57 \mathrm{~b}$ & 27,8 & $92_{b}$ & 26,0 & $14 \mathrm{c}$ & 10,1 \\
\hline & $\begin{array}{l}\text { klasa średnia } \\
\text { niższa }\end{array}$ & $118_{\mathrm{a}}$ & 36,0 & 75 a & 36,6 & $86_{b}$ & 24,3 & $26_{b}$ & 18,7 \\
\hline & $\begin{array}{l}\text { klasa średnia } \\
\text { wyższa }\end{array}$ & $44 a$ & 13,4 & 59 b & 28,8 & $140_{b, c}$ & 39,5 & $68_{c}$ & 48,9 \\
\hline & klasa wyższa & $14 \mathrm{a}$ & 4,3 & $14 \mathrm{a}, \mathrm{b}$ & 6,8 & $36_{b}$ & 10,2 & $31_{c}$ & 22,3 \\
\hline
\end{tabular}

Wartości w tym samym wierszu i podtabeli nie mające tego samego indeksu dolnego (przypisu) znacząco różnią się w wartości $p<0,05 \mathrm{w}$ dwustronnym teście równości dla proporcji kolumnowych.

Źródło: opracowanie własne.

publicznych, $41,5 \%$ - prestiżowych publicznych oraz aż $68,3 \%$ - stołecznych prestiżowych. Przy zaostrzeniu kryterium przynależności do elit poprzez uwzględnienie odsetka studentów, których oboje rodzice ukończyli studia oraz należą do co najmniej klasy średniej wyższej, różnica pomiędzy studentami masowych a studentami prestiżowych uczelni zaciera się, ale pomiędzy stołecznymi oraz prywatnymi a resztą pozostaje zdecydowana - proporcje wynoszą odpowiednio: $1,2 \%$, 5,4\%, 7\% i 23,7\%. Zestawienia wskazują na spore zróżnicowanie studentów badanych typów uczelni pod względem SSE. Szczególnie „odstają” studenci uczelni stołecznych, którzy nie różnią się istotnie od studentów prestiżowych uczelni publicznych jedynie pod względem odsetka osób, których rodzice należą do klasy średniej (niższej i średniej).

Korelacja zawodu z wykształceniem także znajduje potwierdzenie: siła związku między badanymi cechami (współczynnik kontyngencji $V$-Cramera) wynosi $V=0,635$. Jest to umiarkowanie silny związek, uzasadniający osobne uwzględnienie wykształcenia i wykonywanego zawodu w dalszych analizach.

Sytuacja materialna rodziny. Tabela 4 przedstawia statystykę opisową dla zmiennej ilościowej mierzonej na skali 7-stopniowej. Test $t$ dla prób niezależnych wykazał, że tylko różnica między studentami publicznych uczelni masowych a studentami uczelni prestiżowych nie jest istotna statystycznie. Warto jednak zwrócić uwagę, że różnice te nie są znaczne. Korelacja sytuacji materialnej rodziny z zawodem i wykształceniem rodziców jest zaś umiarkowana: wynosi odpowiednio 
Tabela 4. Relatywna sytuacja materialna rodzin studentów

\begin{tabular}{|l|c|c|}
\hline \multicolumn{1}{|c|}{ Kategoria uczelni } & $\begin{array}{c}\text { Średnia } \\
(M)\end{array}$ & $\begin{array}{c}\text { Odchylenie } \\
\text { standardowe }(S D)\end{array}$ \\
\hline Prywatne masowe & 4,45 & 1,43 \\
Publiczne masowe & 4,94 & 1,33 \\
Publiczne prestiżowe & 5,08 & 1,27 \\
Elitarne stoleczne & 5,47 & 1,25 \\
\hline
\end{tabular}

Źródło: opracowanie własne.

Tabela 5. Statystyki opisowe zmiennych ilościowych

\begin{tabular}{|l|c|c|}
\hline \multicolumn{1}{|c|}{ Zmienna ilościowa } & $M$ & $S D$ \\
\hline Sytuacja materialna rodziny & 4,90 & 1,38 \\
Dochód rozporządzalny (zł) & 1755 & 1113 \\
Wyniki maturalne & 152,2 & 31,1 \\
\hline
\end{tabular}

Źródło: opracowanie własne.

0,466 i o,323 (współczynnik Eta dla zmiennych przedziałowych i nominalnych). Podstawowe statystyki ilościowych zmiennych z modelu ukazuje tabela 5 .

Dochód rozporządzalny studentów. Studentów proszono o określenie średniej wysokości środków pieniężnych, jakie mają do dyspozycji miesięcznie w trakcie roku akademickiego (tab. 6).

Tabela 6. Dochód rozporządzalny studentów

\begin{tabular}{|l|c|c|}
\hline \multicolumn{1}{|c|}{ Kategoria uczelni } & $M$ & $S D$ \\
\hline Prywatne masowe & 1981 & 1347 \\
Publiczne masowe & 1580 & 835 \\
Publiczne prestiżowe & 1512 & 892 \\
Elitarne stołeczne & 2097 & 1180 \\
\hline Ogółem & 1755 & 1113 \\
\hline
\end{tabular}

Źródło: opracowanie własne.

Różnica między dochodem rozporządzalnym studiujących na masowych uczelniach prywatnych a stołecznych prestiżowych oraz różnica pomiędzy studentami publicznych uczelni masowych i bardziej prestiżowych, po przeprowadzeniu testu $t$ dla prób niezależnych, okazała się nieistotna statystycznie. Nie można więc stwierdzić, że istnieje w tych przypadkach zróżnicowanie pod względem dochodu rozporządzalnego ${ }^{4}$. Pozostałe różnice należy uznać za znaczne (ok. 25\%), w związ-

4 Przynajmniej w sensie ilościowym - zasadne wydaje się przypuszczenie, że wyższy dochód studentów uczelni prywatnych wynika z powszechnego w ich przypadku godzenia studiów z pracą. 
ku z czym zdecydowano o uwzględnieniu tej zmiennej w modelu. Korelacja Pearsona pomiędzy sytuacją materialną rodziny a dochodem rozporządzalnymi wynosi $0,208 \mathrm{i}$ jest istotna dwustronnie na poziomie $p<0,01$. Uzasadnia to uwzględnienie obu zmiennych w modelu, a także ich powiązanie. Kierunek tego powiązania powinien być jasny: im lepsza sytuacja materialna rodziny, tym więcej środków może ona przekazywać studentowi na pokrycie kosztów utrzymania na studiach oraz dodatkowe wydatki. Chęć przekazywania (i otrzymywania) środków od rodziny będzie z kolei zależeć od charakteru więzi rodzinnych (kapitał społeczny). Relacja dochodu $\mathrm{z}$ wykształceniem i zawodem rodziców nie jest $\mathrm{w}$ wyjściowym modelu zakładana.

Wyniki na maturze. Zgodnie z przewidywaniami raportowane przez respondentów wyniki z egzaminu maturalnego istotnie różnicują studentów poszczególnych rodzajów uczelni (tab. 7). Można także zaobserwować, że wraz ze wzrostem prestiżu uczelni zmniejsza się zmienność wyników maturalnych. Wyniki na maturze wyraźnie powiązane są także z sytuacją materialną rodziny, zawodem i wykształceniem rodziców (tab. 8 i 9). Korelacja Pearsona pomiędzy sytuacją materialną a wynikami na maturze wyniosła $r=0,194$ i okazała się istotna statystycznie na poziomie $p<0,01$ (jednostronnie). Siłę związku należy więc uznać za raczej słabą.

Tabela 7. Średnie wyniki matury (podstawowy język obcy + podstawowa matematyka) studentów poszczególnych rodzajów uczelni

\begin{tabular}{|l|c|c|}
\hline \multicolumn{1}{|c|}{ Kategoria uczelni } & $M$ & $S D$ \\
\hline Prywatne masowe & 132,2 & 29,8 \\
Publiczne masowe & 142,0 & 26,2 \\
Publiczne prestiżowe & 164,5 & 22,5 \\
Elitarne stołeczne & 182,8 & 18,9 \\
\hline Ogółem & 152,2 & 31,1 \\
\hline
\end{tabular}

Wszystkie różnice istotne statystycznie na poziomie $p<0,001$.

Źródło: opracowanie własne.

Tabela 8. Średnie wyniki na maturze w poszczególnych klasach społecznych

\begin{tabular}{|l|c|c|c|}
\hline \multicolumn{1}{|c|}{ Zawód rodziców } & $N$ & $M$ & $S D$ \\
\hline Klasa robotnicza & 315 & 139,5 & 31,4 \\
Klasa średnia-niższa & 305 & 148,3 & 29,1 \\
Klasa średnia-wyższa & 311 & 163,6 & 27,6 \\
Klasa wyższa & 95 & 169,2 & 27,1 \\
\hline
\end{tabular}

Tylko różnica między klasą średnią wyższą a wyższą nie jest istotna statystycznie.

Źródło: opracowanie własne. 
Tabela 9. Średnie wyniki na maturze a wykształcenie rodziców.

\begin{tabular}{|l|c|c|c|}
\hline Wykształcenie rodziców & $N$ & $M$ & $S D$ \\
\hline Brak matury & 300 & 137,7 & 31,4 \\
Matura & 295 & 148,0 & 28,1 \\
Wyższe & 431 & 165,0 & 27,6 \\
\hline
\end{tabular}

Wszystkie różnice istotne statystycznie na poziomie $p<0,000$.

Źródło: opracowanie własne.

Warto także zwrócić uwagę, że średnia wyników na maturze studentów o najniższym SSE (rodzice bez wyższego wykształcenia i pracujący fizycznie) w przypadku każdej kategorii uczelni (nie licząc uczelni stołecznych, na których odnotowano tylko 12 takich osób) jest od 10 do 12 punktów niższa od średniej dla studentów pochodzących z elit społecznych (rodzice z co najmniej średniej wyższej klasy i z wyższym wykształceniem). Sugeruje to, że osoby o niższym SSE dostają się na bardziej prestiżowe uczelnie z niższych pozycji rankingowych. Podsumowując, analiza statystyk opisowych wyraźnie wskazuje, że osiągnięty na maturze wynik ma istotne znaczenie dla wyboru uczelni. Na pytanie, na ile zapośrednicza on wpływ SSE (efekt pierwotny), a na ile wpływ pochodzenia klasowego oddziałuje na ten wybór w sposób niezależny od osiągnięć edukacyjnych, pozwoli odpowiedzieć strukturalna część modelu. Przedtem jednak zaprezentowane zostaną efekty pomiarowego etapu SEM, który miał na celu włączenie do analiz zmiennych w postaci kapitału kulturowego i kapitału społecznego (oddziałujących także na wyniki na maturze).

\section{Wyniki - modelowanie równań strukturalnych (SEM)}

Część po miarowa. Zmienne wymienione w tabelach 10 i 11 miały w założeniu służyć pomiarowi zmiennych ukrytych w postaci kapitału kulturowego (KK) i kapitału społecznego (KS). Konfirmacyjna analiza czynnikowa (CFA) pozwala ocenić własności pomiaru na danej skali, w tym przypadku skali KK i KS. Pomimo osiągnięcia satysfakcjonujących statystyk dopasowania modelu do danych przy uwzględnieniu czterech istotnych statystycznie zmiennych z tabeli 10 i trzech z tabeli 11 nie udało się zapewnić odpowiedniego poziomu trafności pomiaru. Należy więc przypuszczać, że uwzględnione zmienne nie mierzą tego samego - mamy raczej do czynienia z różnymi wymiarami KK i KS, które należałoby w tym kontekście rozumieć jako konstrukty teoretyczne odnoszące się do szeregu odrębnych, realnych zjawisk ${ }^{5}$. Ponadto pomiar charakteryzował się niesatysfakcjonującym

${ }^{5}$ Warto tu przywołać krytykę pozytywistycznej koncepcji „zmiennych ukrytych” z perspektywy naukowego realizmu - zdaniem Roya Nasha nie odzwierciedlają one realnych zjawisk i jako koncepty 
Tabela 10. Wskaźniki kapitału społecznego

\begin{tabular}{|l|c|c|}
\hline \multicolumn{1}{|c|}{ Zmienna } & $M$ & $S D$ \\
\hline Ambicje edukacyjne koleżanek i kolegów z klasy (skala 1-5)* & 3,22 & 1,05 \\
Liczba znajomych, którzy studiują na tej samej uczelni & 5,58 & 7,20 \\
Oczekiwania rodziców wobec wykształcenia (1-7) & 4,31 & 0,87 \\
Wpływ rodziców na decyzję (1-5) & 3,41 & 1,84 \\
Korzystanie z porad i informacji rodziny (1-5) & 2,87 & 1,36 \\
Korzystanie z porad i informacji znajomych i przyjaciół (1-5) & 2,77 & 1,28 \\
\hline
\end{tabular}

* Traktowanie zmiennych mierzonych na skali jako ciągłe jest pewnym uproszczeniem, jednak dopuszczalnym w tego typu badaniach empirycznych.

Źródło: opracowanie własne.

Tabela 11. Wskaźniki kapitału kulturowego

\begin{tabular}{|l|c|c|}
\hline \multicolumn{1}{|c|}{ Zmienna } & $M$ & $S D$ \\
\hline Liczba książek w domu rodzinnym (skala 1-5) & 3,13 & 1,15 \\
Uczęszczanie na zajęcia dodatkowe (1-5) & 3,28 & 1,50 \\
Praktyki czytelnicze: specjalistyczna literatura, prasa, blogi itp. (1-5) & 2,46 & 1,11 \\
Praktyki czytelnicze - powieści (1-5) & 2,74 & 1,18 \\
\hline
\end{tabular}

Źródło: opracowanie własne.

poziomem rzetelności („rho”, odpowiednio: $\rho=0,5$ i $\rho=0,61$ ), czyli proporcji całkowitej zmienności skali wyjaśnianej przez model. W związku z tym traktowanie KK i KS jako zmiennych ukrytych nie znajduje uzasadnienia.

Nie oznacza to jednak, że należy całkowicie zrezygnować z uwzględnienia omawianych zmiennych w modelu wyjaśniającym nierówności. Analiza statystyk opisowych dla zmiennych obserwowalnych wykazała, że wszystkie z nich różnicują studentów co najmniej jednej pary uczelni. Na przykład studenci uczelni stołecznych nie różnią się od studentów publicznych uczelni prestiżowych jedynie w następujących aspektach: liczby znajomych, którzy studiują na tej samej uczelni, oczekiwań rodziców, korzystania z porad i informacji rodziny i przyjaciół. Pod względem częstotliwości lektur powieści nie różnią się także od studentów prywatnych uczelni masowych (być może ze względu na przeciętnie wyższy wiek tych drugich). Generalnie zmienne odnoszące się do kapitału społecznego zdają się różnicować przede wszystkim studentów uczelni prywatnych względem studentów uczelni publicznych, natomiast odnoszące się do kapitału kulturowego - stołecznych względem pozostałych. Wobec tego, zdecydowano się na uwzględnienie

teoretyczne nie mogą być przedmiotem pomiaru, a tym bardziej uwzględniane jako zmienne wyjaśniające w modelu (Nash i Lauder 2010: 242). 
w modelu SEM wszystkich wymienionych w tabeli zmiennych pod postacią odrębnych zmiennych obserwowalnych.

Część strukturalna. Pomimo rezygnacji z zastosowania CFA zastosowanie SEM w zasadniczej części analizy wpływu wyróżnionych zmiennych na podjęcie studiów na uczelni danej kategorii jest wciąż zasadne ze względu na hipotetyzowany ścieżkowy charakter zależności pomiędzy zmiennymi oraz możliwość łatwego modelowania tych zależności. Główne wyzwanie metodologiczne związane z SEM polegało na konieczności testowania zgeneralizowanego modelu (gSEM) ze względu na nominalny charakter zmiennej zależnej oraz zmiennych wskazujących na wykształcenie i pozycję zawodową rodziców. Uniemożliwia to m.in. przeprowadzenie większości charakterystycznych dla SEM testów dobroci dopasowania modelu do danych, oszacowanie standaryzowanych wartości parametrów modelu oraz kalkulację efektów pośrednich, bezpośrednich i łącznych w modelu ścieżkowym. Ponadto nie jest możliwe uwzględnienie korelacji pomiędzy zmiennymi egzogenicznymi (sytuacja materialna rodziny, wykształcenie i zawód rodziców), ale można uznać, że obliczone współczynniki korelacji pomiędzy nimi wykluczają problem współliniowości. Pierwszemu z tych problemów można częściowo zaradzić poprzez przeprowadzenie testów tego samego modelu w ramach standardowego SEM, zakładającego ilościowy charakter wszystkich zmiennych. Jest to akceptowalne w sytuacji, gdy w test chi-kwadrat okazuje się nieistotny statystycznie (Rhemtulla, Brosseau-Liard i Savalei 2012), co ma miejsce w przypadku analizowanego modelu. Drugi z wymienionych problemów częściowo rekompensuje możliwość obliczenia zestandaryzowanych wyników $z$ dla poszczególnych zależności. Trzeci natomiast stwarza barierę nie do przekroczenia ze względu na brak możliwości obliczenia standaryzowanych współczynników beta.

Statystyki dobroci dopasowania zostały przedstawione obok przedstawiającego finalną wersję modelu rysunku 2. Wskazują one na bardzo dobre odzwierciedlenie macierzy wariancji i kowariancji zmiennych przez zaprezentowany model. Co więcej, wyjaśnia on aż 41\% zmienności zmiennej zależnej będącej głównym przedmiotem zainteresowania, czyli podjęcia studiów na uczelni o danej kategorii prestiżu, a także 18\% zmienności innej ważnej dla modelu zmiennej, jaką są wyniki matury.

Tabela 12 prezentuje wyniki oszacowań zależności pomiędzy zmiennymi wyjaśniającymi w modelu. Spośród zmiennych odnoszących się do koncepcji kapitału kulturowego i społecznego, moc eksplanacyjną w kontekście całego modelu okazały się mieć tylko oczekiwania rodziców, częstotliwość uczęszczania na zajęcia dodatkowe, szkolna presja rówieśnicza oraz liczba książek w domu rodzinnym. Warto zauważyć, że wyższe wykształcenie rodziców w istotny statystycznie sposób wpływa na wszystkie analizowane dyspozycje społeczne świadczące o wyposażeniu w kapitał kulturowy i społeczny, a także na wyniki osiągane na maturze. Posiadanie rodziców, którzy zdali co najwyżej maturę - w porównaniu do studentów, których rodzice nie mają tego dyplomu - wpływa pozytywnie jedynie na 


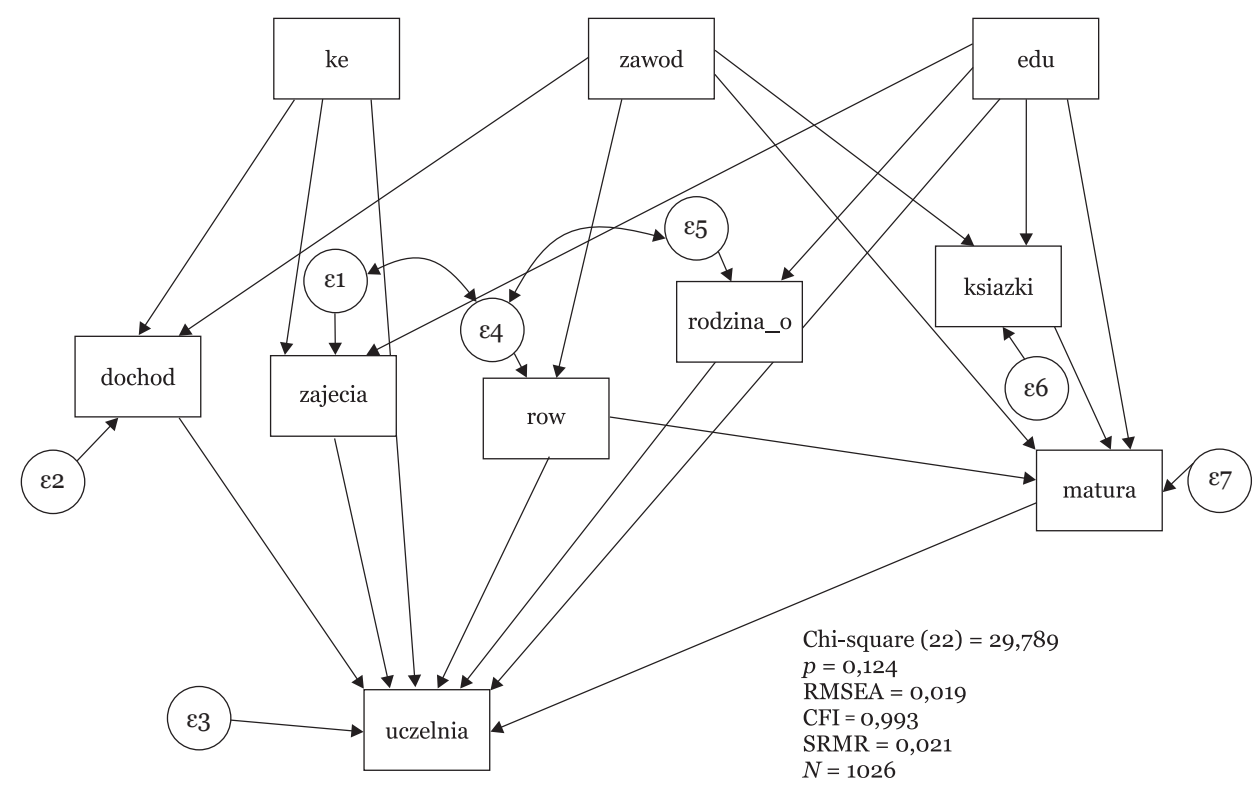

Rysunek 2. Finalny model uwarunkowań wyboru uczelni

1) $R^{2}=0,41$ dla zmiennej „uczelnia”, $R^{2}=0,18$ dla zmiennej „matura”.

2) ke - kapitał ekonomiczny - ocena sytuacji materialnej rodziny; zawod - zawód wykonywany przez rodziców/przynależność klasowa; edu - wykształcenie rodziców; dochod - dochód rozporządzalny studenta w czasie studiów; zajecia - częstotliwość uczęszczania na zajęcia dodatkowe; row - aspiracje edukacyjne rówieśników szkolnych; rodzina_o - oczekiwania rodziców względem wykształcenia; ksiazki - liczba książek w domu rodzinnym; matura - wyniki maturalne; uczelnia - kategoria szkoły wyższej, na której studiuje dana osoba; $\varepsilon$ - błąd pomiaru.

Źródło: opracowanie własne.

środowisko rówieśnicze, w którym funkcjonuje się na etapie szkoły średniej, oraz na liczbę książek w domu rodzinnym. Wyróżnione kategorie położenia klasowego także nie okazały się całkowicie odrębne. Jedynie przynależność do klasy wyższej wpływa pozytywnie na wysokość dochodu dyspozycyjnego studenta w czasie studiów. Wpływ klasy na wyniki matury oraz liczbę książek w domu rodzinnym został potwierdzony tylko dla osób z klasy średniej wyższej i wyższej.

Podsumowując, częstotliwość uczęszczania na zajęcia dodatkowe w ostatniej klasie liceum zależy od sytuacji materialnej rodziny, pozytywnie wpływa na nią także posiadanie rodziców z wyższym wykształceniem. Liczba książek w domu rodzinnym jest pozytywnie skorelowana $\mathrm{z}$ wykształceniem rodziców oraz z wykonywaniem przez nich zawodów stanowiących o przynależności do klasy średniej wyższej i wyższej. Im większy kapitał ekonomiczny rodziny, tym większe jej oczekiwania wobec kariery edukacyjnej dzieci. W podobny sposób wpływa na nie wyższe wykształcenie co najmniej jednego rodzica. Na doświadczanie presji rówie- 
Tabela 12. Strukturalna część modelu - związek pomiędzy zmiennymi wyjaśniającymi

\begin{tabular}{|c|c|c|c|c|}
\hline Zmienna zależna & Predyktor & $b$ & S.E. & $Z$ \\
\hline \multirow[t]{9}{*}{ matura } & row & $4,29^{* * * *}$ & 0,84 & 5,09 \\
\hline & ksiazki & $2,95^{* * *}$ & 0,81 & 3,64 \\
\hline & \multicolumn{4}{|c|}{ zawod } \\
\hline & kns & $-1,46$ & 2,96 & $-0,49$ \\
\hline & kss & $7,18^{*}$ & 3,27 & 2,20 \\
\hline & $\mathrm{kw}$ & $9,01^{*}$ & 4,30 & 2,10 \\
\hline & \multicolumn{4}{|c|}{ edu } \\
\hline & maturalne & $8,93^{* *}$ & 2,92 & 3,05 \\
\hline & wyższe & $18,53^{* * *}$ & 3,28 & 5,66 \\
\hline \multirow[t]{4}{*}{ zajecia } & ke & $0,19^{* * *}$ & 0,03 & 5,36 \\
\hline & \multicolumn{4}{|c|}{ edu } \\
\hline & maturalne & 0,10 & 0,12 & 0,82 \\
\hline & wyższe & $0,54^{* * *}$ & 0,11 & 4,70 \\
\hline \multirow[t]{5}{*}{ dochod } & ke & $132,22^{* * *}$ & 27,76 & 4,76 \\
\hline & \multicolumn{4}{|c|}{ zawod } \\
\hline & kns & 84,26 & 87,46 & 0,96 \\
\hline & kss & 83,86 & 92,01 & 0,91 \\
\hline & $\mathrm{kw}$ & $477,31^{* *}$ & 138,96 & 3,43 \\
\hline \multirow[t]{4}{*}{ rodzina_o } & ke & $0,09^{* * *}$ & 0,02 & 4,50 \\
\hline & \multicolumn{4}{|c|}{ edu } \\
\hline & maturalne & 0,13 & 0,07 & 1,83 \\
\hline & wyższe & $0,27^{* * *}$ & 0,07 & 4,05 \\
\hline \multirow[t]{4}{*}{ row } & \multicolumn{4}{|c|}{ zawod } \\
\hline & kns & $0,21^{*}$ & 0,08 & 2,55 \\
\hline & kss & $0,27^{* *}$ & 0,08 & 3,21 \\
\hline & $\mathrm{kw}$ & $0,39^{* *}$ & 0,12 & 3,18 \\
\hline \multirow[t]{7}{*}{ ksiazki } & \multicolumn{4}{|c|}{ zawod } \\
\hline & kns & $-0,03$ & 0,11 & $-0,27$ \\
\hline & kss & $0,34^{* *}$ & 0,13 & 2,72 \\
\hline & $\mathrm{kw}$ & $0,66^{* * *}$ & 0,16 & 4,02 \\
\hline & \multicolumn{4}{|c|}{ edu } \\
\hline & maturalne & $0,3^{* *}$ & 0,11 & 2,69 \\
\hline & wyższe & $0,56^{* * *}$ & 0,13 & 4,45 \\
\hline $\operatorname{cov}($ e.row,e.zajecia) & & $0,1^{*}$ & 0,05 & 2,12 \\
\hline cov(e.row,e.rodzina_o) & & $0,1^{* * *}$ & 0,03 & 3,78 \\
\hline
\end{tabular}

1) ${ }^{*} p<0,05,{ }^{* *} p<0,01,{ }^{* *} p<0,001$

2) objaśnienia jak na rys. 2, ponadto: kns - klasa niższa średnia; kss - klasa średnia średnia; kw - klasa wyższa; maturalne - matura najwyższym poziomem wykształcenia wśród rodziców; wyższe - co najmniej jeden z rodziców ma wyższe wykształcenie.

Źródło: opracowanie własne. 
śniczej związanej z aspiracjami edukacyjnymi koleżanek i kolegów z klasy w szkole średniej pozytywnie wpływa wykonywany przez rodziców zawód, co jest zapewne konsekwencją szerszego zjawiska związanego ze stratyfikacją szkolnictwa w Polsce, czyli podziału na szkoły masowe i elitarne (nierzadko prywatne), do których na ogół trafiają dzieci osób z wyższych klas społecznych (Dolata 2010). Na znaczenie środowiska szkolnego wskazują także istotne statystycznie korelacje pomiędzy błędami pomiaru zmiennych: oczekiwania rodziców, aspiracje rówieśników szkolnych oraz uczęszczanie na zajęcia pozaszkolne. Związki między nimi nie są silne, jednak sugerują pewne współwystępowanie, które może być konsekwencją oddziaływania czynnika nieuwzględnionego w analizie, np. charakteru pracy pedagogicznej w danym środowisku szkolnym czy w ogóle relacji społecznych w szkole, które w mniejszym lub większym stopniu mogą sprzyjać kształtowaniu pozytywnych postaw wobec wymagań systemu szkolnictwa.

Jeśli zaś chodzi o wyniki na egzaminie maturalnym, to oszacowane parametry wskazują na szczególnie silną rolę wyższego wykształcenia rodziców i aspiracji edukacyjnych rówieśników. Potwierdzony został także pozytywny wpływ dostępu do zasobów kulturowych w domu rodzinnym (mierzonego liczbą książek), przynależności do klasy średniej wyższej oraz wyższej, a także posiadania przez rodziców matury jako najwyższego poziomu edukacyjnych kwalifikacji. Można także zauważyć, że zgodnie z postawionymi hipotezami dochód dyspozycyjny zależy od kapitału ekonomicznego rodziny, a także od przynależności rodziców do klasy wyższej. Relacje rodzinne $\mathrm{w}$ tej klasie społecznej sprzyjają zatem czerpaniu przez studentów środków finansowych z rodzinnego budżetu.

Tabela 13 przedstawia z kolei parametry tych zmiennych z modelu finalnego, które mają bezpośredni wpływ na studiowanie na uczelni danej kategorii. Zgeneralizowany tryb SEM umożliwia testowanie modelu z nominalnym zmiennymi zależnymi, przyjmując własności wielomianowej regresji logistycznej. Jedną z nich jest możliwość oszacowania ilorazów szans (odds ratios - $\exp (b)$ w tabeli 13). Służą one ocenie, jak dana zmienna wpływa na prawdopodobieństwo „wyboru” jednej kategorii zmiennej zależnej względem prawdopodobieństwa „wyboru” drugiej kategorii, przy niezmienności pozostałych czynników w modelu. W kontekście postawionych pytań badawczych są więc bardziej adekwatnym narzędziem interpretacji wyników niż inne współczynniki obliczane na podstawie $b$, które pokazują o jaką wielkość zmienia się prawdopodobieństwo wyboru jednej, konkretnej kategorii wraz ze wzrostem danej zmiennej o jednostkę ${ }^{6}$.

Interpretacja poszczególnych współczynników exp (b), które okazały się istotne statystycznie, przebiega następująco: na podstawie zgromadzonych danych można powiedzieć, że wzrost częstotliwości uczęszczania na zajęcia dodatkowe w ostatniej klasie liceum o jedną jednostkę zwiększa prawdopodobieństwo podjęcia stu-

${ }^{6}$ Tym bardziej że badaniem nie były objęte osoby, które nie podjęły studiów. 
Tabela 13. Strukturalna część modelu - zmienne warunkujące wybór uczelni

\begin{tabular}{|c|c|c|c|c|}
\hline & $\exp (b)$ & $b$ & S.E. & $z$ \\
\hline \multicolumn{5}{|c|}{ Zajęcia dodatkowe } \\
\hline ES vs. PuP & 1,167 & 0,155 & 0,099 & 1,82 \\
\hline ES vs. PuM & $1,357^{* *}$ & $0,305^{* *}$ & 0,131 & 3,16 \\
\hline ES vs. PrM & $1,392^{* *}$ & $0,331^{* *}$ & 0,135 & 3,42 \\
\hline PuP vs. PuM & $1,162^{*}$ & $0,151^{*}$ & 0,075 & 2,33 \\
\hline PuP vs. PrM & $1,193^{* *}$ & $0,176^{* *}$ & 0,077 & 2,75 \\
\hline PuM vs. PrM & 1,026 & 0,026 & 0,066 & 0,40 \\
\hline \multicolumn{5}{|c|}{ Dochód rozporządzalny } \\
\hline ES vs. PuP & $1,000680^{* * *}, 40,5 \%$ & $0,000680^{* * *}$ & 0,000136 & 5,01 \\
\hline ES vs. PuM & $1,000419^{* *}, 23,3 \%$ & $0,000419^{* *}$ & 0,000147 & 2,84 \\
\hline ES vs. PrM & $0,999772^{*},-10,8 \%$ & $-0,000228^{*}$ & 0,000102 & $-2,24$ \\
\hline PuP vs. PuM & 0,999739 & $-0,000262$ & 0,000152 & $-1,72$ \\
\hline PuP vs. PrM & $0,999093^{* * *},-36,5 \%$ & $-0,000908^{* * *}$ & 0,000131 & $-6,93$ \\
\hline PuM vs. PrM & $0,999354^{* * *},-27,6 \%$ & $-0,000646^{* * *}$ & 0,000132 & $-4,90$ \\
\hline \multicolumn{5}{|c|}{ Aspiracje rówieśników } \\
\hline ES vs. PuP & $1,288^{*}$ & $0,253^{*}$ & 0,154 & 2,12 \\
\hline ES vs. PuM & $1,639^{* * *}$ & $0,494^{* * *}$ & 0,227 & 3,57 \\
\hline ES vs. PrM & $1,655^{* * *}$ & $0,504^{* * *}$ & 0,230 & 3,63 \\
\hline PuP vs. PuM & $1,272^{*}$ & $0,241^{*}$ & 0,119 & 2,58 \\
\hline PuP vs. PrM & $1,285^{* *}$ & $0,251^{* *}$ & 0,119 & 2,70 \\
\hline PuM vs. PrM & 1,010 & 0,010 & 0,093 & 0,11 \\
\hline \multicolumn{5}{|c|}{ Oczekiwania rodziny } \\
\hline ES vs. PuP & $1,485^{*}$ & $0,396^{*}$ & 0,252 & 2,33 \\
\hline ES vs. PuM & $1,664^{* *}$ & $0,509^{* *}$ & 0,315 & 2,69 \\
\hline ES vs. PrM & $1,942^{* * *}$ & $0,664^{* * *}$ & 0,362 & 3,56 \\
\hline PuP vs. PuM & 1,120 & 0,114 & 0,133 & 0,96 \\
\hline PuP vs. PrM & $1,308^{*}$ & $0,268^{*}$ & 0,147 & 2,38 \\
\hline PuM vs. PrM & 1,167 & 0,155 & 0,128 & 1,41 \\
\hline \multicolumn{5}{|c|}{ Wyniki matury } \\
\hline ES vs. PuP & $1,0499^{* * *}, 62,7 \%$ & $0,0487^{* * *}$ & 0,0078 & 6,59 \\
\hline ES vs. PuM & $1,0845^{* * *}, 125,2 \%$ & $0,0812^{* * *}$ & 0,0086 & 10,22 \\
\hline ES vs. PrM & $1,0967^{* * *}, 151,7 \%$ & $0,0923^{* * *}$ & 0,0088 & 11,54 \\
\hline PuP vs. PuM & $1,0330^{* * *}, 38,3 \%$ & $0,0324^{* * *}$ & 0,0040 & 8,44 \\
\hline PuP vs. PrM & $1,0446^{* * *}, 54,7 \%$ & $0,0436^{* * *}$ & 0,0041 & 11,17 \\
\hline PuM vs. PrM & $1,0112^{* *}, 11,9 \%$ & $0,0112^{* *}$ & 0,0035 & 3,26 \\
\hline \multicolumn{5}{|c|}{ Sytuacja materialna rodziny } \\
\hline ES vs. PuP & 0,884 & $-0,123$ & 0,089 & $-1,23$ \\
\hline ES vs. PuM & 0,892 & $-0,114$ & 0,102 & $-1,00$ \\
\hline ES vs. PrM & 1,169 & 0,156 & 0,132 & 1,39 \\
\hline PuP vs. PuM & 1,009 & 0,009 & 0,078 & 0,12 \\
\hline
\end{tabular}


cd. tabeli 13

\begin{tabular}{|c|c|c|c|c|}
\cline { 2 - 5 } \multicolumn{1}{c|}{} & $\exp (b)$ & $b$ & S.E. & $z$ \\
\hline PuP vs. PrM & $1,323^{* * *}$ & $0,280^{* * *}$ & 0,100 & 3,72 \\
PuM vs. PrM & $1,311^{* * *}$ & $0,271^{* * *}$ & 0,098 & 3,61 \\
\hline \multicolumn{4}{|c|}{ Wykształcenie wyższe rodzica } \\
\hline ES vs. PuP & $2,968^{* *}$ & $1,088^{* *}$ & 1,203 & 2,68 \\
ES vs. PuM & $3,279^{* *}$ & $1,188^{* *}$ & 1,445 & 2,69 \\
ES vs. PrM & $9,181^{* * *}$ & $2,217^{* * *}$ & 4,088 & 4,98 \\
PuP vs. PuM & 1,105 & 0,100 & 0,271 & 0,41 \\
PuP vs. PrM & $3,093^{* * *}$ & $1,129^{* * *}$ & 0,789 & 4,42 \\
PuM vs. PrM & $2,800^{* * *}$ & $1,030^{* * *}$ & 0,711 & 4,06 \\
\hline
\end{tabular}

1) ${ }^{*} p<0,05,{ }^{* *} p<0,01,{ }^{* * *} p<0,001$.

2) ES - elitarne stołeczne; PuP - publiczne prestiżowe; PuM - publiczne masowe; PrM - prywatne masowe.

Źródło: opracowanie własne.

diów na elitarnych uczelniach stołecznych względem publicznych, prestiżowych uczelni, o 35,7\%. W podobny sposób należy interpretować pozostałe oszacowane współczynniki, mając na uwadze, że $\exp (b)$ to współczynnik multiplikatywny: „1” oznacza brak efektu, $\exp (b)>1$ oznacza wpływ pozytywny danej zmiennej wyjaśniającej, a $\exp (b)<1$ - negatywny7. Ilorazy szans dla dochodu rozporządzalnego i wyników matury zostały przeliczone na procenty (podane za wartościami współczynnika) według wzoru:

$$
\text { procentowa zmiana prawdopodobieństwa }=100\left\{\exp \left(\delta \beta_{k}\right)-1\right\}
$$

gdzie:

$\delta$ - jednostka zmiany dochodu lub wyników matury (przyjęto odpowiednio: 500 zł i 10 pkt),

$\beta_{k}$ - współczynnik „b” z tabeli 13 dla danej zmiennej.

A zatem jeżeli dochód rozporządzalny danej osoby zwiększyłby się o 500 zł, to iloraz szans studiowania na uczelni elitarnej, a nie prestiżowej publicznej zwiększylby się o 40,5\%. Miałoby to natomiast negatywny wpływ na prawdopodobieństwo studiowania na publicznej uczelni masowej zamiast na prywatnej - wielkość współczynnika spada tu o 27,6\%. Do ostatniego wyniku należy jednak podejść ostrożnie. Wątpliwe, by oznaczał on, że im więcej środków pieniężnych może mieć/ma dana osoba, tym większe prawdopodobieństwo, że wybierze uczelnię prywatną zamiast publicznej. Jest to raczej dowód na to, że studenci uczelni prywatnych częściej

7 Należy także przypomnieć, że współczynniki te nie są wystandaryzowane, w związku z czym nie można powiedzieć, że np. zajęcia dodatkowe wpływają na studiowanie na elitarnej, a nie masowej uczelni w mniejszym stopniu niż aspiracje rówieśników szkolnych, ponieważ $\exp (b)=1,357<\exp (b)$ =1,639. Można natomiast porównywać pary kategorii $\mathrm{w}$ ramach tej samej zmiennej wyjaśniającej. 
lub w większym wymiarze czasu pracują, co pozwala im osiągnąc wyższy poziom dochodu rozporządzalnego w czasie studiów od studentów uczelni publicznych.

Można zauważyć, że jedyną zmienną, która wpływa na każdą „parę” uczelni są wyniki matury. Jest to czynnik, który zdaje się oddziaływać na wybór uczelni danej kategorii w sposób najsilniejszy. W największym stopniu różnicuje on studentów uczelni uważanych za prestiżowe względem tych, którzy zapisują się na uczelnie masowe. Na podstawie tabeli 12 wywnioskowano, że to, jak osoba z danej grupy poradzi sobie na maturze, jest dużej mierze konsekwencją strukturalnych czynników w postaci wykonywanego zawodu rodziców oraz wykształcenia rodziców. Istotne jest przy tym zarówno to, czy co najmniej jeden rodzic ma maturę, jak i to, czy ukończył studia. Opracowany model wskazuje, że wykształcenie rodziców wywiera także bezpośredni wpływ na podejmowane przez młodzież decyzje o podjęciu studiów na danej uczelni. W tym zakresie udowodniono ,jedynie” znaczenie wyższego wykształcenia rodziców ${ }^{8}$. Znaczące różnice, które można zaobserwować w tabeli 3, znajdują więc dodatkowe uzasadnienie. Szczególnie wyraźna jest w tym zakresie różnica pomiędzy studentami elitarnych uczelni stołecznych a prywatnych uczelni masowych.

Inna zmienna o charakterze strukturalnym - kapitał ekonomiczny odzwierciedlony w sytuacji materialnej rodziny, wpływa pozytywnie na prawdopodobieństwo wyboru publicznych uczelni prestiżowych lub masowych zamiast uczelni prywatnej. Zważywszy na to, że zmienna ta nie wpływa na wyniki matury nawet w sposób zapośredniczony, można powiedzieć, że stojący przed takim wyborem (a więc spełniający kryteria kwalifikacji) studenci z rodzin o niższym statusie ekonomicznym częściej decydują się na podjęcie studiów na uczelni prywatnej, czyli płatnych i na ogół bardziej sprzyjających godzeniu studiowania z pracą zawodową. Pośrednio sytuacja materialna rodziny wywiera także wpływ na dochód rozporządzalny studenta, będący kolejnym czynnikiem niezależnie różnicującym studentów, szczególnie uczelni stołecznych względem pozostałych publicznych. Możliwość otrzymywania dodatkowych środków pieniężnych mogłaby istotnie wpłynąć na uwzględnianie możliwości studiowania na elitarnych uczelniach warszawskich w procesie decyzyjnym szczególnie tych osób, które wybierają się na prestiżowe uczelnie publiczne $\mathrm{w}$ innych ośrodkach akademickich. Jest to zrozumiałe $\mathrm{w}$ kontekście przeciętnie wyższych kosztów życia w stolicy. Obserwacja ta pozwala na spekulacje, na ile rozkład efektywnego popytu mógłby być kształtowany przez system stypendiów, kredytów studenckich i opłat za studia, których wysokość byłaby $\mathrm{w}$ większym stopniu zróżnicowana $\mathrm{z}$ uwagi na koszty życia w danym mieście oraz prestiż danej uczelni.

${ }^{8}$ Pozostałe kategorie tej zmiennej nie zostały zamieszczone w tabeli 13, gdyż nie wpływają one na żadną alternatywę pomiędzy kategoriami uczelni. 
Studiowanie na uczelni danej kategorii okazało się także uzależnione od kapitału społecznego, czyli w tym przypadku aspiracji edukacyjnych rówieśników szkolnych oraz oczekiwań rodziców wobec wykształcenia danej osoby. Istotne są też praktyki, które można uznać za powiązane ze środowiskiem szkolnym, mianowicie częstotliwość uczęszczania na zajęcia dodatkowe. Warto zauważyć, że w trakcie modelowania, w celu osiągnięcia odpowiedniego poziomu dopasowania modelu do danych, konieczne okazało się usunięcie z modelu większości zmiennych świadczących o posiadaniu sprzyjających (w teorii) osiągnięciom edukacyjnym dyspozycjach - korzystania z sieci kontaktów w celu poprawy jakości posiadanej informacji o możliwościach studiowania, a także różnych praktyk czytelniczych (ucieleśniony kapitał kulturowy) ${ }^{9}$.

Odnosząc się do uwzględnionych aspektów kapitału kulturowego i społecznego, należy wskazać na wyraźnie zarysowującą się różnicę pomiędzy studentami uczelni prestiżowych a masowych - ci pierwsi zdecydowanie częściej uczestniczyli $\mathrm{w}$ zajęciach dodatkowych w ostatniej klasie liceum, co nie miało jednak istotnego statystycznie wpływu na wyniki osiągane na maturze, lecz kształtowało najwyraźniej aspiracje do studiowania na jak najlepszej uczelni, być może dzięki pozytywnym informacjom zwrotnym ze strony korepetytora. Podobnie oddziałują wysokie aspiracje rówieśników z klasy - jedyną różnicą jest ich pozytywny wpływ na prawdopodobieństwo wyboru elitarnej uczelni społecznej, a nie prestiżowej publicznej. Prawdopodobieństwo wyboru prestiżowej uczelni rośnie wraz ze wzrostem oczekiwań rodziców co do wykształcenia dziecka, które częściowo zapośredniczają wpływ wykształcenia na wybór. Co ciekawe, nie stwierdzono w tym względzie różnicy pomiędzy prestiżowymi uczelniami publicznymi a masowymi, czynnik ten nie wpływa też na to, którą uczelnię masową dana osoba wybierze.

Na ile wyniki matury są decydujące w omawianej kwestii? Różnica wpływu tej zmiennej w stosunku do pozostałych jest bowiem dosyć znaczna. Innymi słowy, jest to pytanie o to, czy w kontekście różnic SSE studentów uczelni o różnym prestiżu można mówić o istnieniu efektu wtórnego? Aby to ocenić, porównano dwa modele z wykorzystaniem relatywnych miar dopasowania modeli do danych: AIC (Akaike information criterion) i BIC (Bayesian information criterion). Porównano trzy modele: (1) model finalny, (2) model finalny bez bezpośrednich zależności pomiędzy wymienionymi w tabeli 13 zmiennymi wyjaśniającymi a wyborem uczelni (oprócz wpływu wyników matury), (3) model różniący się od drugiego obecnością dodatkowych parametrów: wpływu zmiennych usuniętych z modelu finalnego na wyniki na maturze. Wyniki przedstawia tabela 14.

9 Nie należy oczywiście wnioskować, że czynniki te nie mają znaczenia - ich nieistotność statystyczna w relacji do innych zmiennych może równie dobrze wynikać z niewłaściwego pomiaru. W istocie działanie kapitału społecznego i kulturowego w kontekście edukacji dużo łatwiej uchwycić w badaniach jakościowych (Jæger i Holm 2007). 
Tabela 14. Efekt pierwotny a efekt wtórny - porównanie modeli

\begin{tabular}{|c|c|c|c|}
\hline Model & $d f$ & AIC & BIC \\
\hline 1 & 51 & 41446,24 & 41771,84 \\
2 & 33 & 41637,94 & 41800,75 \\
3 & 37 & 41639,43 & 41821,97 \\
\hline
\end{tabular}

Źródło: opracowanie własne.

Różnice wartości kryteriów informacji dostarczają argumentów za uznaniem modelu (1) za najlepiej dopasowany do danych. Są zatem podstawy, by uznać istnienie znaczącego efektu wtórnego w omawianym kontekście, co pozwala potwierdzić hipotezę drugą o istnieniu w Polsce horyzontalnych nierówności w dostępie do kształcenia na poziomie wyższym.

\section{Podsumowanie}

Przeprowadzone badanie dostarcza empirycznych dowodów na istnienie znacznego zróżnicowania studentów w Polsce pod względem statusu społeczno-ekonomicznego (SSE). Zróżnicowanie to jest widoczne pomiędzy studentami uczelni o różnym prestiżu. Uprzywilejowanym pochodzeniem społecznym szczególnie wyróżniają się studenci elitarnych uczelni stołecznych. Analiza czynników odpowiedzialnych za to zróżnicowanie, uwzględnionych w zaprezentowanym na rysunku 2 modelu, pozwala wyciągnąc kilka ogólnych wniosków. Po pierwsze, największe znaczenie wśród zmiennych stanowiących o SSE danej osoby ma to, czy co najmniej jeden z jej rodziców ma wyższe wykształcenie. Po drugie, model zyskuje dodatkowy potencjał eksplanacyjny dzięki uwzględnieniu tych czynników związanych ze SSE, które można zlokalizować na poziomie dyspozycji i praktyk jednostek, a które związane są głównie z kapitałem społecznym aktywizowanym w kontekście relacji z rówieśnikami w szkole, rodzicami (presja rodzicielska) oraz kapitałem kulturowym przekazywanym podczas zajęć pozaszkolnych i kształtującym aspiracje edukacyjne. Satysfakcjonujące wyjaśnienie mechanizmów stojących za powiązaniami statystycznymi wymagałoby badań o charakterze jakościowym. Po trzecie, choć decydujące znaczenie dla podjęcia studiów na danej uczelni mają wyniki z egzaminu maturalnego, istnieją także silne dowody na to, że część studentów, którzy mogliby dostać się na „lepsze” uczelnie, podejmuje studia na uczelniach masowych (czasami płacąc za nie) ze względu na swoją sytuację ekonomiczną lub uwarunkowania społeczne ograniczające ich aspiracje. Tym samym, możemy mówić o istnieniu w Polsce nierówności horyzontalnych w dostępie do szkolnictwa wyższego.

Jakie wynikają z tego konsekwencje dla polityki edukacyjnej, która stawiałaby przed sobą zadanie ograniczania nierówności szans edukacyjnych, w tym nie- 
równości w dostępie do kształcenia na poziomie wyższym? Po stronie popytowej jednym z możliwych rozwiązań wydaje się oddziaływanie na sytuację finansową potencjalnych studentów poprzez oferowanie stypendiów, kredytów studenckich i opłat za studia dostosowanych do kosztów życia i oczekiwanego zwrotu z inwestycji w kształcenie na danej uczelni. Efektywność i sprawiedliwość różnych rozwiązań w tym zakresie zasługuje na odrębną analizę. Przeprowadzone badania wstępne sugerują zaś minimalny wpływ obecnego systemu finansowania kształcenia wyższego na podejmowane przez studentów decyzje edukacyjne (Czarnecki i Zając 2015). Po stronie podażowej warto wspomnieć o trzech instytucjonalnych rozwiązaniach stosowanych w państwach, które doświadczały umasowienia szkolnictwa wyższego przed Polską. Pierwszym jest utrzymywanie w miarę wyrównanego poziomu wydatków publicznych przypadających na studenta każdej uczelni, drugim - wyrównywanie łącznych nakładów na jednego studenta, trzecim, najdalej idącym i jednocześnie najmniej realnym w polskim kontekście - dążenie do zrównania warunków kształcenia we wszystkich instytucjach prowadzących studia na danym kierunku (Marginson 1997). Ogólnoświatowe trendy w polityce szkolnictwa wyższego, narastająca w Polsce polaryzacja regionów oraz dyskurs interesariuszy wspierają raczej formowanie się jeszcze bardziej elitarnych uczelni i kierunków. Zdają się znacząco ograniczać możliwość zastosowania w Polsce jakichkolwiek rozwiązań po stronie podażowej, zwłaszcza w kontekście dość dużej autonomii uczelni. Stosowanie rozwiązań po stronie popytowej wpisywałoby się natomiast $\mathrm{w}$ zachodnią tradycję realizowania polityki wyrównywania szans bez zmiany zasad gry polegającej na konkurencji o dobro pozycjonalne w postaci dyplomu (a coraz częściej także elitarnych sieci społecznych), w której liczba zwycięzców i przegranych jest stała, a pewne grupy społeczne znajdują się na z góry przegranej pozycji. Pewnym wyjściem, nienaruszającym jednak reprodukcyjnej funkcji pełnionej przez dokonujące selekcji społecznych, zhierarchizowane uczelnie wyższe, byłoby wbudowanie w system finansowania szkolnictwa wyższego mechanizmów redystrybucyjnych zwiększających środki na walkę z nierównościami innymi niż edukacyjne.

\section{Literatura}

Borowicz, R. (1976). Selekcje społeczne $w$ toku kształcenia $w$ szkole wyższej. Warszawa: PAN.

Borowicz, R. (1988). Równość i sprawiedliwość społeczna. Warszawa: PAN, Instytut Rozwoju Wsi i Rolnictwa.

Boudon, R. (1974). Education, Opportunity and Social Inequality: Changing Prospects in Western Society. New York: John Wiley \& Sons.

Bourdieu, P. (1986). The forms of capital. W: J.G. Richardson (red.). Handbook of theory and research for the sociology of education (241-258). New York: Greenwood Press.

Bourdieu, P. (1998). Practical Reason. On the Theory of Action. Stanford: Stanford University Press. 
Bourdieu, P., Passeron, J.-C. (2006). Reprodukcja. Elementy teorii systemu nauczania. Warszawa: Wyd. Naukowe PWN.

Breen, R., Goldthorpe, J.H. (1997). Explaining educational differentials: Towards a formal rational action theory. Rationality and Society. 9: 275-305.

Breen, R., Jonsson, J.O. (2005). Inequality of Opportunity in Comparative Perspective: Recent Research on Educational Attainment and Social Mobility. Annual Review of Sociology. 31: 223-243.

Busemeyer, M. R., Nikolai, R. (2010). Education. W: F. G. Castles, S. Leibfried, J. Lewis, H. Obinger, Ch. Pierson (red.). The Oxford Handbook of the Welfare State (1-10). Oxford: Oxford University Press.

Chattopadhyay, S. (2012). Education and Economics. Disciplinary Evolution and Policy Discourse. Oxford: Oxford University Press.

Checchi, D. (2006). The Economics of Education. Oxford: Oxford University Press.

Collins, R. (1979). Credential Society. London: Academic Press.

Czarnecki, K. (2013). Polski system szkolnictwa wyższego a funkcje polityki społecznej - ujęcie porownawcze. Polityka Spoleczna. 10(475): 25-32.

Czarnecki, K. (2014). The Higher Education Policy of 'Post-Communist Countries' in the Context of Welfare Regimes. Poznan University of Economics Review. 2(15): 43-62.

Czarnecki, K., Zając, T. (2015). Pomoc materialna dla studentów a decyzje kandydatów na studia na Uniwersytecie Ekonomicznym w Poznaniu i Uniwersytecie Warszawskim. Edukacja Ekonomistów i Menadżerów. Problemy. Innowacje. Projekty. 3(37) - w druku.

DiMaggio, P., Mohr, J. (1985). Cultural Capital, Educational Attainment, and Marital Selection. American Journal of Sociology. 90: 1231-1261.

Dolata, R. (2010). Cicha rewolucja w oświacie - proces różnicowania się gimnazjów w dużych miastach. Edukacja. Studia, Badania, Innowacje. 1(105): 60-67.

Domański, H. (2004). Selekcja pochodzeniowa do szkoły średniej i na studia. Studia Socjologiczne. 2: 65-93.

Erikson, R., Goldthorpe, J.H. (1992). The Constant Flux. A Study of Class Mobility in Industrial Societies. Oxford: Oxford University Press.

Graaf, N.D. de, Graaf, P.M. de, Kraaykamp, G. (2000). Parental Cultural Capital and Educational Attainment in the Netherlands: A Refinement of the Cultural Capital Perspective. Sociology of Education. 73: 92-111.

Hällsten, M. (2010). The Structure of Educational Decision Making and Consequences for Inequality: A Swedish Test Case. The American Journal of Sociology. 116: 806-854.

Hart, C.S. (2012). Aspirations, Education and Social Justice: Applying Sen and Bourdieu. London: Bloomsbury.

Herbst, M., Rok, J. (2014). Equity in an Educational Boom: lessons from the expansion and marketisation of tertiary schooling in Poland. European Journal of Education. 49(3): 435-450.

Hoxby, C., Avery, Ch. (2013). The Missing “One-Offs”: The Hidden Supply of High-Achieving, Low-Income Students. Brookings Papers on Economic Activity. 46(1): 1-65.

Jackson, M. (red.) (2013). Determined to Succeed? Performance versus Choice in Educational Attainment. Stanford: Stanford University Press.

Jæger, M.M., Holm, A. (2007). Does Parents Economic, Cultural, and Social Capital Explain the Social Class Effect on Educational Attainment in the Scandinavian Mobility Regime? Social Science Research. 36: 719-744. 
Kline, R.B. (2011). Principles and Practice of Structural Equation Modelling. New York: The Guilford Press.

Knowles, J. (2000). Access for few? Student funding and its impact on aspirations to enter higher education. Widening Participation and Lifelong Learning. 2(1): 14-23.

Kraaykamp, G., Tolsma, J., Wolbers, M.H.J. (2013). Educational expansion and field of study: trends in the intergenerational transmission of educational inequality in the Netherlands. British Journal of Sociology of Education. 34: 888-906.

Kwiek, M. (2014). Changing Higher Education and Welfare States in Postcommunist Central Europe: New Contexts Leading to New Typologies? Human Affairs. 24: 48-67.

Lin, N. (1999). Social networks and status attainment. Annual Review of Sociology. 25: 467-487.

Lucas, S.R. (2001). Effectively Maintained Inequality: Education Transitions, Track Mobility, and Social Background Effects. American Journal of Sociology. 106: 1642-1690.

Marginson, S. (1997). Educating Australia: Government, economy and citizen since 1960. Cambridge: Cambridge University Press.

Marginson, S. (2004). Competition and Markets in Higher Education: a "glonacal" analysis. Policy Futures in Education. 2(2): 175-244.

Martin, N.D., Spenner, K. (2009). Capital Conversion and Accumulation: A Social Portrait of Legacies at an Elite University. Research in Higher Education. 50: 623-648.

Mikiewicz, P. (2014). Kapitał społeczny i edukacja. Warszawa: Wyd. Naukowe PWN.

Nash, R., Lauder, H. (2010). Explaining Inequalities in School Achievement. A Realist Analysis. Farnham: Ashgate.

OECD (2014). Education at a Glance. Paris: OECD.

Pascarella, E.T., Terenzini, P.T. (2005). How college affects students: A third decade of research. San Francisco: Jossey-Bass.

Paulsen, M.B. (1990). College choice: Understanding student enrollment behavior. ASHE-ERIC Higher Education Report 9o-6. Washington: The George Washington University.

Perna, L. (2010). Toward a More Complete Understanding of the Role of Financial Aid in Promoting College Enrollment: The Importance of Context. W: J.C. Smart (red.). Higher Education: Handbook of Theory and Research, Dordrecht: Springer.

Reimer, D., Pollak, R. (2010). Educational Expansion and Its Consequences for Vertical and Horizontal Inequalities in Access to Higher Education in Germany. European Sociological Review. 26(4): 415-430.

Rhemtulla, M., Brosseau-Liard, P.É., Savalei, V. (2012). When can categorical variables be treated as continuous? A comparison of robust continuous and categorical SEM estimation methods under suboptimal conditions. Psychological Methods. 17(3): 354-373.

Rivera, L.E. (2015). Pedigree: How Elite Students Get Elite Jobs. Princeton: Princeton University Press.

Sawiński, Z. (2013). Alicja w krainie nierówności. Recenzja książki Alicji Zawistowskiej: „Horyzontalne nierówności edukacyjne we współczesnej Polsce”. Edukacja. 1(121): 113-118.

Sawiński, Z., Stasińska, M. (1986). Przemiany $w$ oddziaływaniu czynników pochodzenia społecznego na dwóch progach selekcji międzyszkolnej. Warszawa: Instytut Socjologii Uniwersytetu Warszawskiego.

Shavit, Y., Arum, R., Gamoran, A. (red.) (2007). Stratification in Higher Education. A Comparative Study. Stanford: Stanford University Press. 
Stankiewicz, Ł. (2014). Spór o edukację wyższą w perspektywie teorii dóbr pozycjonalnych. Teraźniejszość - Człowiek - Edukacja. 66(2): 109-130.

Szambelańczyk, J. (1982). Zmiany struktury ekonomiczno-społecznej ludności polski a zapotrzebowanie na wyższe wykształcenie. Warszawa: PWN.

Teichler, U. (red.) (2007). Careers of University Graduates. Views and Experiences in Comparative Perspectives. Amsterdam: Springer.

Triventi, M. (2013). Stratification in Higher Education and its Relationship with Social Inequality: A Comparative Study of 11 European Countries. European Sociological Review. 29(3): 489-502.

Wasielewski, K. (2013). Młodzież wiejska na uniwersytecie. Droga na studia, mechanizmy alokacji, postawy wobec kształcenia. Toruń: Wyd. Naukowe UMK.

Zawistowska, A. (2012). Horyzontalne nierówności edukacyjne we wspótczesnej Polsce. Warszawa: Scholar.

\section{Conditions of horizontal inequalities in access to higher education in Poland}

ABSTRACT. The article presents the findings from the study of socio-economic status (SES) of students of several Polish higher education institutions that differ in prestige. The author tries to answer the following question: what determines individual choices of which tertiary school to study at? The question is particularly seminal in the context of Polish higher education system, which can be rightly perceived to be highly stratified in prestige and quality of schools and very diverse in terms of social composition of student body, the latter being, inter alia, the reflection of the higher education expansion processes. The literature on inequality of educational opportunity explicitly shows that students of higher education institutions of different prestige differ significantly in their social background. This hypothesis clearly holds in the light of data collected for this study. This allows one to make a second hypothesis: horizontal inequalities in access to Polish higher education are evident. They imply a situation, in which some school leavers enrol at higher education institutions of lower prestige for reasons other than their educational achievement (fulfilling admission criteria). The article not only proves the existence of horizontal inequalities, but also identifies the demand-side factors that bring them about and assesses their relative strength. The study is based on the survey which has been conducted in the second quarter of 2015 on the sample of Polish first and second year bachelor students in economic disciplines at both public and private tertiary schools in Poland.

KEYWORDS: inequalities of educational opportunities, higher education, socio-economic status

CYTOWANIE: Czarnecki, K. (2015). Uwarunkowania nierówności horyzontalnych w dostępie do szkolnictwa wyższego w Polsce. Nauka i Szkolnictwo Wyższe. 1(45): 161-189. DOI: 10.14746/nsw. 2015.1.7. 